\title{
The Party Line
}

\author{
Paul Gronke
}

\begin{abstract}
$\mathbf{T}$ HIS ISSUE REPRESENTS the end of my first year as editor of Election Law Journal (ELJ), and friends of the Journal will be happy to learn that it continues to expand and thrive. In partnership with Graeme Orr, our international editor, our submissions from outside the United States continue to grow. Doug Chapin has taken the reins as policy editor, and new content will be added to the Journal from election administrators and policymakers in the coming issues. Compared to this same time last year, article downloads from the Journal have increased 90\%, and our readership outside the United States is heaviest in India and Australia-both surely a credit to the special issue on Indian Election Law (11:2) and Prof. Orr's promotion of the Journal in Australia.

The current issue continues our tradition of combining original research articles with focused symposia on topics of interest to the community. Particular credit is due to Professors Edward Foley and Piers Norris Turner, who helped organize and edit a set of commentaries on Bruce Cain's new book, Democracy More or Less: America's Political Reform Quandary. It is particularly appropriate that this forum, consisting of articles by professors of philosophy, law, history, and political science, appears in an interidisciplinary journal like ELJ.

Finally, following what is an increasing standard in academic publishing, accepted articles will now appear in a "Fast Track" section on the Mary Ann Liebert, Inc. website (http://online.liebertpub.com/elj). This assures that important and timely research and policy articles are available to the scholarly community as rapidly as possible.
\end{abstract}

Paul Gronke is editor of Election Law Journal, a professor at Reed College in Portland, OR, and is the Daniel B. German Endowed Visiting Professor at Appalachian State University in Boone, NC. 